\title{
LOYALIST INSTRUCTION OF KAIRSU: SECTION 14 (O. NMEC 339)
}

\section{Marwa A. EWAIS}

Lecturer, Faculty of Archaeology, Fayoum University, Egypt

E-mail: maa24@fayoum.edu.eg

\begin{abstract}
This paper publishes the hieratic ostracon (O. NMEC 339) stored in the National Museum of Egyptian Civilization at Cairo, discovered during Edda Bresciani's excavations at Gurna in Thutmose IV temple in the 1970s. Its exact provenance in the temple is unknown, but it is among a group of hieratic ostraca that was found. The ostracon is a literary fragment inscribed with section 14 of a Loyalist Instruction of Kairsu, considered one of the important literary texts from the Middle Kingdom and New Kingdom. This ostracon is a novel addition to the $18^{\text {th }}$ Dynasty corpus of this composition, which is better known from its Ramesside version.
\end{abstract}

\section{KEYWORDS}

Ostraca- Gurna- Loyalist instruction- $\$ 14$ from Kairsu loyalist- $18^{\text {th }}$ Dynasty-National Museum of Egyptian civilization (NMEC).
الملخص ل O. NMEC تهدف هذه الدراسة الي نشر الثقافة 339 والمحفوظة بمتحف الحضارة بالفسطاط

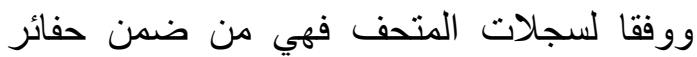
معبد تحتمس الرابع في منتصف السبعينات في

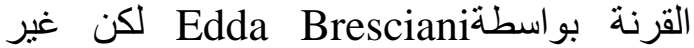
مذكور بالتحديد مكان العثور عليها بالمعبد وهي التئي ضمن مجموعة من الاوستر اكا الهير اطيقية التي لفي تم العثور عليها في نفس المكان. وتمثل هذه

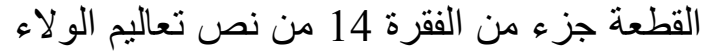

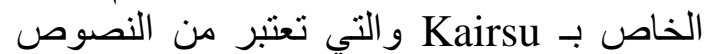
الادبية الهامه التي ظهرت ابتداء من عصر الدولة التئلة

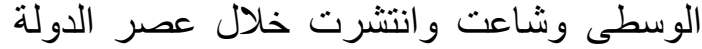
الحديثة. تكمن أهمية نشر هذه القطعة في انها

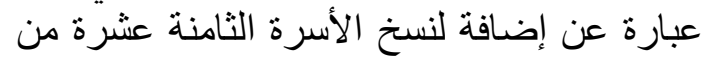

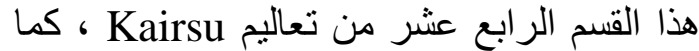

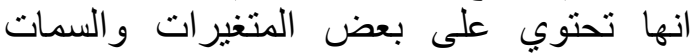
مقارنة بنسخ عصر الرعامسة من هذا النص. الكثمات الدالة

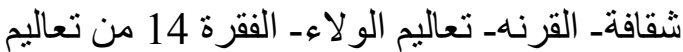
Kairsu

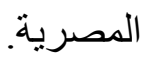

\section{INTRODUCTION}

The instructions are part of the broader genre of the Egyptian wisdom literature. ${ }^{1}$ In Middle Kingdom compositions, the 'instructions' or 'teachings' have frequently the

I would like to thank Prof. Fredrik Hagen for recognising and identifying the text and many thanks to Prof. Maher Eissa for his revision. Sincere thanks also go to the editors and anonymous referees of the Shedet.

${ }^{1}$ Buzov, E., 'Notes on Egyptian Wisdom texts,' JES IV (2015), 61- 62; Lichtheim, M., Moral Values in Ancient Egypt, Orbis Biblicus et Orientalis 155. Fribourg, Switzerland: University Press; Göttingen: Vandenhoek und Ruprecht. (1997), 7; Schneider, Th., 'Scribes, Sages, and Seers in Ancient Egypt,' in Leo G. Perdue (eds.), Scribes Sages, and Seers: The Sage in the Eastern Mediterranean World, Forschungen zur Religion und Literatur des Alten und Neuen Testaments 219. Göttingen: Vandenhoek und Ruprecht, (2008), 34; Williams, R., 'The Sages of Ancient Egypt in the Light of Recent Scholarship,' JAOS 101 (1981), 1, 7. 
term $s b 3 . y t$ in their title and starts with h3.t- ${ }^{\circ} m$ sb3.yt ir.n NN, 'beginning of the instruction made by $\mathrm{NN}$ '. ${ }^{1}$ New Kingdom instructions were introduced by the term $s b$ 3.it-mtr.t ${ }^{2}$ making them distinct from earlier instances without creating a new separate genre. $^{3}$

Lichtheim divided the genre of instructions into three sub-groups: real, royal, and loyalist. ${ }^{4}$ They were used in an educational context, ${ }^{5}$ particularly since the Second Intermediate Period and with more intensity during the Ramesside Period. ${ }^{6}$ The wisdom literature texts were an individual activity usually copied by the student himself not dictated. ${ }^{7}$ This is supported by the lack of dates on the ostraca. However, Ragazzoli ${ }^{8}$ suggested that the literary texts go beyond the school context (teaching and training) during the New Kingdom, as it reflects the scribal professional activities and Egyptian scribal identity.

The Loyalist Instruction of Kairsu could be considered the ideological attempt to justify and strengthen the authority of the pharaoh, in an explicit appeal to the subordinate being loyal to its sovereign ${ }^{9}$ and responsible of subordinates and workers of lower social standing. ${ }^{10}$ The scribe shows in the instruction the objective of bringing the monarchic institution back to its top place by exalting the king ${ }^{11}$ and respecting dependents to avoid problems for their masters as a kind of application the social concept of $m 3{ }^{\mathrm{C}} t .^{12}$ It may be

\footnotetext{
${ }^{1}$ The Instruction of Amenemhat I (P. Millingen, $\left.\S \mathrm{H} 1 \mathrm{a}\right)$, the Instruction of Khety $(\mathrm{P}$. Sallier II = P. BM EA $10182, \S 1.1)$, the Instruction of Hordjedef (O. Munich 3400, § H1.1), the Instruction of a Man for His Son (L. BM EA 10258, $\S ~ 0.1-0.2)$, the Loyalist Instruction of Kairsu (P. Rifeh = P. London UC 32781, 1.1). The beginning is absent from the fragmentary instructions of Oxford, for Kagemni, of P. Ramsseum II, and of Lahun.

${ }^{2}$ For instance the instructions of Ani and of Amennakht. See also Silva, A., The Roles of God in the Ancient Egyptian Instruction Texts of the Middle and New Kingdoms, PhD thesis, Universidade de Lisboa (2019), 64, 65.

${ }^{3}$ Dorn, A., 'Die Lehre Amunnachts,' Z̈̈S 131, (2004), 51. However, Fredrik Hagen suggested that teachings were used as authoritative sources for behavioural principles. Hagen, F., An Ancient Egyptian Literary Text in Context. The Instruction of Ptahhotep, 40-1 \& 209-10.

${ }^{4}$ Lichtheim, M., 'Didactic Literature,' in Loprieno, A. (ed.) Ancient Egyptian Literature. History and Forms, Leiden - New York - Koln, (1996), 243.

${ }^{5}$ Williams, R., 'Scribal Training in Ancient Egypt,' JAOS 92 (1972), 215-217; Fox, M. V., 'The Social Location of the Book of Proverbs,' in Fox, M. V. (eds.) Texts, Temples, and Traditions: A Tribute to Menahem Haram, Victor Avigdor Hurowitz, Avi Hurvitz, Michael L. Klein, Baruch J. Schwartz, and Nili Shupak, Winona Lake, Indiana: Eisenbrauns, (1996), 229.

${ }^{6}$ Hagen, F., An Ancient Egyptian Literary Text in Context: The Instruction of Ptahhotep, Orientalia Lovaniensia Analecta 218. Leuven: Peeters, (2012), 64; Parkinson, R. B., Poetry and Culture in Middle Kingdom Egypt: A Dark Side to Perfection, London: Continuum, (2002), 235-36.

${ }^{7}$ Burkard, G., Textkritische Untersuchungen zu ägyptischen Weisheitslehren des Alten und Mittleren Reiches, Äg.Abh 34, (1977), 68-71, 142-145.

${ }^{8}$ Ragazzoli, Ch., 'La littérature de scribe au Nouvel Empire ou pourquoi les miscellanées ne sont pas des textes scolaires,' BSFE 201, (2019), 44-78.

${ }^{9}$ Posener,G., L'enseignement loyaliste. Sagesse égyptienne du Moyen Empire,15-16.

${ }^{10}$ For a basic edition, see Posener, G., L'enseignement loyaliste. Sagesse egyptienne du Moyen Empire. Geneva: Droz. (1976), in addition, cf. Chappaz, J.-L. 'Un nouvel ostracon de l'Enseignement loyaliste,' $B S E ́ G$ 7, (1982), 7; Verhoeven, U., 'Von der 'Loyalistischen Lehre' zur 'Lehre des Kai'rsu,' Z\#̈S 136, (2009), 87-98; Hagen, F., New Kingdom Ostracafrom the Fitzwilliam Museum. Cambridge. Leiden: Brill. (2011), $25 \mathrm{f}$.

${ }^{11}$ Carreira J. N., Filosofia antes dos Gregos, Biblioteca universitária 71, (1994), 117-118.

${ }^{12}$ Canhão, T., A literatura egípcia do Império Médio: espelho de uma civilização, $\mathrm{PhD}$ thesis, University of Lisbon, (2010), 448.
} 
divided into two distinct sets: the first set consists of section 1 to section 8 or 9 , and the second set from section 8 or 9 to section $14{ }^{1}$

Middle Kingdom attestations preserve the first set of the text up to section 6, referred to as the "short version". The remaining attestations from the New Kingdom add to this version, reaching a full extension and a "long version". ${ }^{2}$ Pascal Vernus suggested that the version on the Sehetepibre stela is abridged from the complete later text. ${ }^{3}$ On the other hand, for James Allen, later sources innovate and expand on the Middle Kingdom text. ${ }^{4}$

The first part of the Loyalist presents the king as a champion of Egypt, and a series of his military virtues are exposed, as well as his ability to speak well, highlighting his leadership. ${ }^{5}$ This is the part preserved in the stela of Sehetepibre found in the temple of Osiris in Abydos (Egyptian Museum, Cairo, CG 20538) which dates from the reign of King Amenemhat III in the $12^{\text {th }}$ Dynasty. ${ }^{6}$ It is usually seen as the "short version" of the text or, better said, the "Shortened version". The second part of this text refers to all those who are subordinate and their indispensability. ${ }^{7}$ The final sentences of stanza 14 appear in the stela of Rehuankh from Abydos (Berlin 7311), dated to the reigns of Neferhotep I and Sebekhotep IV in the $13^{\text {th }}$ Dynasty. ${ }^{8}$

For the New Kingdom, the Loyalist instruction of Kairsu is known by three papyri (P. Louvre E 4864 recto, ${ }^{9}$ Papyrus Amherst XII + XIII, ${ }^{10}$ Papyrus UC 32781), ${ }^{11}$ and the wooden tablet called the Carnarvon II tablet (Cairo JE 43261D). ${ }^{12}$ A large number of literary ostraca come from the tomb workers' village of Deir el-Medina and its surrounding areas. Fredrik Hagen estimates the number of Instructions of Kairsu copied on ostraca at Deir el-Medina to be 70 copies, ${ }^{13}$ to which the present ostracon should be added. Among a series of literary graffiti on the tomb N13.1 of the nomarch Iti-ibi-iqer at Assiut of the $11^{\text {th }}$ Dynasty, section 1 of the Loyalist instruction of Kairsu was found.

\footnotetext{
${ }^{1}$ As for the division of this instruction, see Vernus, P, Sagesses de l'Égypte pharaonique. 2nd ed. rev. Arles: Actes Sud, (2010), 265-66; Schipper, B, 'Von der "Lehre des Sehetp-jb-Re" zur "Loyalistischen Lehre”. Überlegungen zur Überlieferungsgeschichte loyalistischer Aussagen,’ ZÄS 125, (1998), 162 n7. ${ }^{2}$ Silva, A., The Roles of God in the Ancient Egyptian Instruction Texts of the Middle and New Kingdoms, 143.

${ }^{3}$ Vernus, P., Sagesses de l'Égypte pharaonique, 265; He was followed in this suggestion by Canhão, T., Textos da literatura egípcia do Império Médio: Textos hieroglíficos, transliterações e traduções comentadas. Lisbon: Fundação Calouste Gulbenkian, (2014), 831.

${ }^{4}$ Allen, J., Middle Egyptian Literature: Eight Literary Works of the Middle Kingdom, Cambridge: Cambridge University Press, (2015), 155.

${ }^{5}$ Leprohon, R.J., 'The Stela of Sehetepibre (CG 20538) Borrowings and Innovation,' in Silverman, D.P.; Simpson, W.K and Wegner, J.(eds.), Archaism and Innovation: Studies in the Culture of Middle Kingdom Egypt, Yale University, (2009), 277- 290.

${ }^{6}$ Vernus, P., Sagesses de l'Égypte pharaonique, 265; Leprohon, R.J., in Silverman, D.P.; Simpson, W.K.and Wegner, J.(eds.), Archaism and Innovation: Studies in the Culture of Middle Kingdom Egypt, Yale University, (2009), 277- 290.

${ }^{7}$ Canhão, T., A literatura egípcia do Império Médio: espelho de uma civilização, 422.

${ }^{8}$ Berlev, O.D.,'Une méthode pour dater les stèles du Moyen-Empire (la formule: "Ôvous, les vivants, ceux qui sont sur terre"),' КСИНА 46, (1962), 45-87.

${ }^{9}$ Posener,G., L'enseignement loyaliste. Sagesse égyptienne du Moyen Empire, 144

${ }^{10}$ Posener,G., L'enseignement loyaliste. Sagesse égyptienne du Moyen Empire, 5-6

${ }^{11}$ Posener,G., L'enseignement loyaliste. Sagesse égyptienne du Moyen Empire, 6-7.

12 Posener,G., L'enseignement loyaliste. Sagesse égyptienne du Moyen Empire, 143; Griffith, F., 'Carnarvon tablets I and II,' in Carnarvon and Carter (eds.), Five years' explorations at Thebes: a record of work done 1907-1911, Oxford (1912), 37-pl. 29; For Carnarvon Tablet II, see Lilyquist, C. 'Twelve Carnarvon Writing Boards and their Provenances,' JEA 105 (2019), 157-175; Hagen, F. 'New Copies of Old Classics,' JEA 105 (2019), 177-208.

${ }^{13}$ Hagen, F., An Ancient Egyptian Literary Text in Context: The Instruction of Ptahhotep, 84, 246.
} 
The importance of this graffiti is seen in that it introduces the name of the author of the extended version. ${ }^{1}$

\section{THE AUTHOR OF THE LOYALIST INSTRUCTION}

Loprieno states that authors of loyalist instructions avoided mentioning three main elements that could generate conflict: 'anonymity', 'god v king', and 'success in life $\mathrm{v}$ survival after death'. ${ }^{2}$

The author of the Middle Kingdom version of the Instruction remains unknown. Various schools have argued the potential identities of this individual. ${ }^{3}$ Since the discovery of the graffiti in the tomb $\mathrm{N} 31.1$ at Assiut that includes the beginning of the text, ${ }^{4}$ previously referred to as Loyalist Instruction, author's name is known as Kairsu. As a result researchers have adopted the term Loyalist Instruction of Kairsu. ${ }^{5}$ Hence Kairsu was considered to be the author only based on New Kingdom sources. Kairsu was one of the eight great authors of ancient Egypt, according to Pap. Chester Beatty IV dating to the $19^{\text {th }}$ Dynasty. ${ }^{6}$

\section{O. NMEC 339}

Description: The Ostracon NMEC 339 (figs. 1-2) is a fragment of hieratic ostracon ${ }^{7}$ roughly $9 \mathrm{~cm}$ wide and $11 \mathrm{~cm}$ long. The convex side is inscribed with 5 horizontal lines of hieratic from the end of the literary text "the Instruction of Kairsu". The text has verse points in black ink. The surface is damaged at the right and left corners and parts of the beginning and end of the three lines of text have disappeared. The sherd is not complete.

Provenance: In 1896, Flinders Petrie discovered the mortuary temple of Thutmose IV in Gurna but it was in great decay. ${ }^{8}$ From 1973 to 1981, the Pisa mission led by Edda Bresciani undertook fieldwork on this site. The mission completed the work in the temple of Thutmose IV and the surrounding area. Many fragments of ceramic vessels, including fragments of hieratic ostraca, were recovered in the temple area. ${ }^{9}$

The lack of detailed information about the find-spot of the hieratic fragments in Edda Bresciani's reports led to the loss of the social context of these ostraca. Only one

\footnotetext{
${ }^{1}$ Verhoeven, U., 'Von der „Loyalistischen Lehre" zur „Lehre des Kairsu” Eine neue Textquelle in Assiut und deren Auswirkungen Hierzu Tafel XII,' ZÄS 136 (2009), 87-88.

${ }^{2}$ Loprieno, A., 'Loyalistic Instructions,' in Loprieno, A., Ancient Egyptian Literature: History and Forms, Probleme der Ägyptologie 10. Leiden: Brill, (1996), 404-412.

${ }^{3}$ For example, Georges Posener suggested that the author of Loyalist Instruction was Ptahemdjehuti, Posener, Litterature et politique, 34.

${ }^{4}$ Verhoeven, U., Z̈̈S 136 (2009), 87-98.

${ }^{5}$ Hagen, F., An Ancient Egyptian Literary Text in Context: The Instruction of Ptahhotep. Orientalia Lovaniensia Analecta 218, Leuven: Peeters, (2012), ix.

${ }^{6}$ p. BM EA 10684 verso, col. III, 5 - 7; Gardiner, A. H., Chester Beatty Gift, HPBM $3^{\text {rd }}$ series, London (1935), Tf. 19; Verhoeven, U., ZÄS 136 (2009), 91.

${ }^{7}$ This ostracon is part of collection. See: Nassar, M\& Eissa, M., 'Hieratic wine jar dockets from Tuthmosis's IV temple in Gurna,' SHEDET 7 (2020), 26- 38; Ewais, M \&Eissa, M., 'Unpublished Administrative Ostraca from Gurna,' ZÄS, (forthcoming).

${ }^{8}$ Petrie, F., Six Temples at Thebes 1896, London, (1897), 7-8.

${ }^{9}$ Bresciani, E., 'l'attivita' archeologica dell'Universita' di Pisa in Egitto: 1977-1980: Tebe (Gurna): $1977-$ 1980,' EVO 3, (1980), 1-8.
} 
ostracon was indicated to have been found in the 'House of Bread (the oven)' of the funerary temple of Thutmose IV. ${ }^{1}$

Dating: The only criterion available for dating the ostracon is handwriting. Based on the list of ostraca from the Temple of Millions of Years of Thutmose III $^{2}$ and Amherst XII + XIII fragments, ${ }^{3}$ this ostracon dates to the end of the $18^{\text {th }}$ Dynasty.

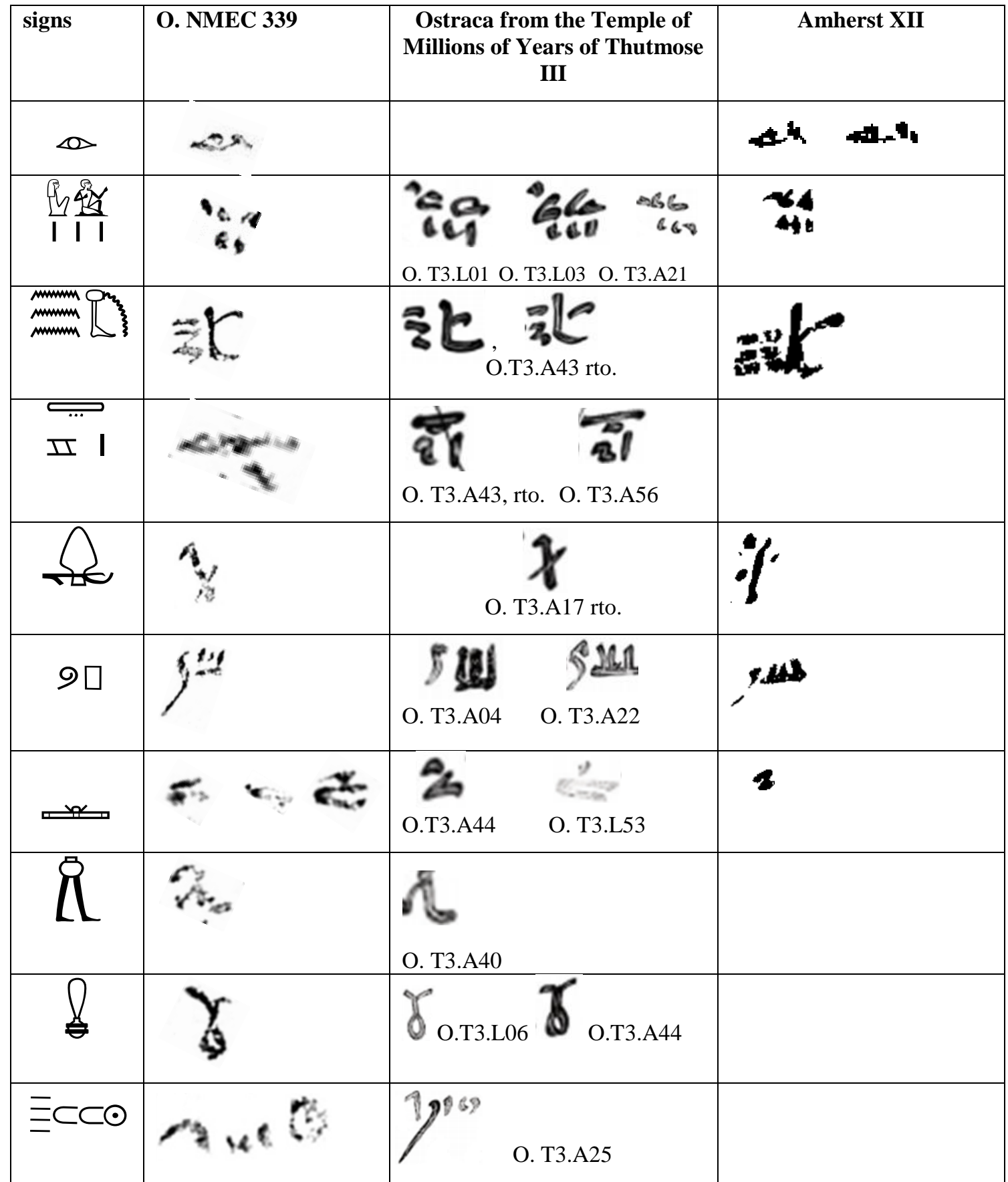

Table 1: Similar signs between O. NMEC 339, Ostraca from the Temple of Millions of Years of Thutmose III and Amherst XII

${ }^{1}$ Bresciani, E., EVO 3, (1980), 7-8. For this ostracon and other ostraca found in the temple, see Ewais, M and Eissa, M., 'Unpublished Administrative Ostraca from Gurna,' Z̈̈S, No. NMEC No. 406 (figs. 1012), (forthcoming).

${ }^{2}$ Hagen, F., Ostraca from the Temple of Millions of Years of Thutmose III, Leiden, (2021).

${ }^{3}$ Posener,G., L'enseignement loyaliste. Sagesse égyptienne du Moyen Empire, 5-6 


\section{Transcription:}

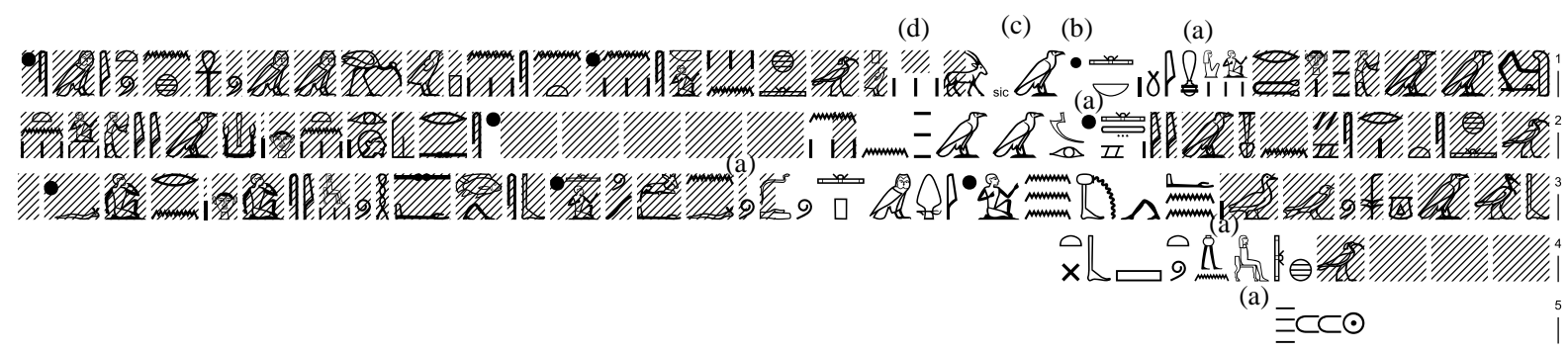

\section{Transliteration}

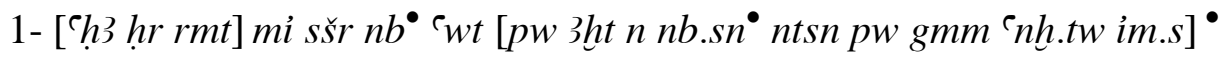

2- [3h st r-sy $n]$ sm $3 y t ~ t 33^{\bullet} m 33 . w n n[\ldots . . .]^{\bullet}$ [sts tp.tn hr hmw-k3.tn]

3- [b3gsw s3] ${ }^{\complement} n n w^{\complement} b^{\bullet} i 3 m p w \underline{d} d w\left[n \text {.f iw } 3^{\bullet} \text { bs s }{ }^{\top} h \text { nis hr rn.f }\right]^{\bullet}$

4- [...........] 3h šsp in tw šbt

5- $\quad s w 24$

\section{Translation:}

1- [Fight for people $]^{(1)}$ in every way ${ }^{(2)}{ }^{\bullet}\left[\right.$ they are] the flock $^{(3)}$ [that is good for their lord ${ }^{\bullet}$ It is they who find what one lives on it $\left.{ }^{\circ}\right]^{(4)}$

2-[they are very useful] for burial ${ }^{\bullet}$. They look to us ${ }^{(5)}[\ldots . . .]^{\bullet}[$ watch over your ka priests]

3 -[if the son is neglectful] the pure-priest still returns ${ }^{(6)} \cdot[$ the one says about the heir is] the one who A pleasant ${ }^{(7)} \bullet$

$4-[\ldots .$.$] the blessed dead, bring { }^{(8)}$ the food-offerings ${ }^{(9)}$.

5- day $24^{(10)}$.

\section{Content:}

This ostracon represents part of section 14 of the loyalist instruction of Kairsu. The instruction of Kairsu was part of the literary canon of New Kingdom Egypt and a text that most scribes would have read. ${ }^{1}$

The presence of this literary ostracon in the temple of Thutmose IV highlights the importance of the temple school during the $18^{\text {th }}$ Dynasty. Christian Leblanc ${ }^{2}$ and Barbotin $^{3}$ assumed that the large temples on the Theban West Bank dating to the New Kingdom had scribal schools attached to them.

Thanks to the discovery of many literary ostraca inside temples, such as the Ramesseum, ${ }^{4}$ the temple of Merenptah, ${ }^{5}$ or the temple of Thutmose III, Hagen suggested that the scribal schools in New Kingdom temples were not limited to religious and priestly education only. They also included various aspects of life, copies of

\footnotetext{
${ }^{1}$ Hagen, F., New Kingdom Ostraca from the Fitzwilliam Museum, 25.

${ }^{2}$ Leblanc, C., 'L'école du temple (ât-sebait) et le per-ankh (maison de vie). Á propos de récentes découvertes effectuées dans le contexte du Ramesseum', Memnonia 15, (2004), 93-101.

${ }^{3}$ Barbotin, C., 'Les ostraca hiératiques de l'école du Ramesseum', Memnonia 24, (2013), 73-79.

${ }^{4}$ After the finding of about 100 literary exercises in the south-east corner of the magazine area, Brunner H., Altägyptische Erziehung, 2nd ed, Wiesbaden, (1991), 18; Janssen R.M. and Janssen, Jac. J., Growing Up in Ancient Egypt, London, (1990), 76; Leblanc, C., Memnonia 15, (2004), 93-101; Barbotin, C., Memnonia 24, (2013), 73-79.

${ }^{5}$ Müller, M. 'Ostraka aus dem Totentempel des Merenptah in Theben', in Toivari-Viitala; J. Vartiainen, T.; Uvanto S. (eds.), Deir el-Medina Studies: Helsinki June 24-26, 2009 Proceedings (The Finnish Egyptological Society Occasional Publications 2). Vantaa: Multiprint, (2014), 144-153.
} 
classical literary works, in majority wisdom instructions. ${ }^{1}$ This literary fragment could result from the training of priests in the temple.

In this section, Kairsu instructs his children to respect subordinates and uphold their allotted duties in society. ${ }^{2}$ His children are advised to avoid rebellion against the king, as the follower of the king will become a venerable person. There is no burial for anyone who rebels against the king. His corpse will be thrown into the water.

Posener first compiled the texts of 9 ostraca as the basis for his reconstruction of section 14 of the Loyalist Instruction of Kairsu. However, many of these copies are incomplete and damaged. The discovery of a new attestation of this section of the text is significant. The following list details the 11 sources for section 14 of the Loyalist Instruction of Kairsu.

\begin{tabular}{|c|c|c|c|c|}
\hline Sources & Content & Date & $\begin{array}{c}\text { Provenanc } \\
\text { e }\end{array}$ & Publication \\
\hline $\begin{array}{l}\text { P. Louvre } \\
\text { E4864 }\end{array}$ & $\begin{array}{l}\S 3, \S 4, \S 5, \S 6, \S 7, \\
\S 8, \S 9, \S 10, \S 11, \\
\S 12, \S 13, \S 14\end{array}$ & $\begin{array}{l}18^{\text {th }} \\
\text { Dynasty }\end{array}$ & Unknown & $\begin{array}{l}\text {-Posener, } \quad \mathrm{G} ., \quad \text { L'enseignement } \\
\text { loyaliste. Sagesse égyptienne du } \\
\text { Moyen Empire, } 144\end{array}$ \\
\hline $\begin{array}{l}\text { P. Amherst } \\
\text { XII+XIII }\end{array}$ & $\begin{array}{l}\$ 10, \S 11, \S 12, \\
\S 13, \S 14\end{array}$ & $\begin{array}{l}\text { End of } \\
18^{\text {th }} \\
\text { Dynasty }\end{array}$ & Unknown & $\begin{array}{l}\text {-Posener, } \quad \mathrm{G} ., \quad \text { L'enseignement } \\
\text { loyaliste. Sagesse égyptienne du } \\
\text { Moyen Empire, 5-6 }\end{array}$ \\
\hline $\begin{array}{l}\text { Tablet } \\
\text { Carnarvon II }\end{array}$ & $\begin{array}{l}\$ 8, \S 9, \S 10, \S 11, \\
\S 12, \S 13, \S 14\end{array}$ & $\begin{array}{l}17^{\text {th }}-18^{\text {th }} \\
\text { Dynasty }\end{array}$ & $\begin{array}{l}\text { Deir el } \\
\text { Bahari }\end{array}$ & $\begin{array}{l}\text {-Posener, G., L'enseignement } \\
\text { loyaliste. Sagesse égyptienne du } \\
\text { Moyen Empire, } 143 \text {. } \\
\text {-Griffith, F., "Carnarvon tablets I } \\
\text { and II," in Carnarvon and Carter } \\
\text { (eds.), Five years' explorations at } \\
\text { Thebes: a record of work done } \\
\text { 1907-1911, Oxford (1912), 37-pl. } 29\end{array}$ \\
\hline $\begin{array}{l}\text { Ostracon IFAO } \\
\text { Cat. } 1236\end{array}$ & $\$ 14$ & $\begin{array}{l}19^{\text {th }}-20^{\text {th }} \\
\text { Dynasty }\end{array}$ & $\begin{array}{l}\text { Deir el } \\
\text { Medina }\end{array}$ & $\begin{array}{l}\text {-Posener, G., Catalogue des ostraca } \\
\text { hiératiques littéraires de Deir el } \\
\text { Médineh, Tome } 2 \text { (Nos } 1109 \text { à } \\
\text { 1266), DFIFAO 18, 1951, 35, pl. } \\
\text { 59-59 a. }\end{array}$ \\
\hline $\begin{array}{l}\text { Ostracon IFAO } \\
\text { Cat. } 1238\end{array}$ & $\S 13, \S 14$ & $\begin{array}{l}19^{\text {th }}-20^{\text {th }} \\
\text { Dynasty }\end{array}$ & $\begin{array}{l}\text { Deir el- } \\
\text { Medina }\end{array}$ & $\begin{array}{l}\text {-Posener, G., Catalogue des ostraca } \\
\text { hiératiques, } 35 \text {, pl. } 60-60 \text { a. }\end{array}$ \\
\hline $\begin{array}{l}\text { Ostracon IFAO } \\
\text { Cat. } 1241\end{array}$ & $\$ 14$ & $\begin{array}{l}19^{\text {th }}-20^{\text {th }} \\
\text { Dynasty }\end{array}$ & $\begin{array}{l}\text { Deir el- } \\
\text { Medina }\end{array}$ & $\begin{array}{l}\text {-Posener, G., Catalogue des ostraca } \\
\text { hiératiques, 36, pl. 61-61 a. }\end{array}$ \\
\hline $\begin{array}{l}\text { Ostracon IFAO } \\
\text { Cat. } 1244\end{array}$ & $\$ 14$ & $\begin{array}{l}19^{\text {th }}-20^{\text {th }} \\
\text { Dynasty }\end{array}$ & $\begin{array}{l}\text { Deir el- } \\
\text { Medina }\end{array}$ & $\begin{array}{l}\text {-Posener, G., Catalogue des ostraca } \\
\text { hiératiques, 36-37, pl. 61-61 a. }\end{array}$ \\
\hline $\begin{array}{l}\text { Ostracon IFAO } \\
\text { Cat. } 1418\end{array}$ & $\$ 14$ & $\begin{array}{l}19^{\text {th }}-20^{\text {th }} \\
\text { Dynasty }\end{array}$ & $\begin{array}{l}\text { Deir el- } \\
\text { Medina }\end{array}$ & $\begin{array}{l}\text {-Posener, G., Catalogue des ostraca } \\
\text { hiératiques, 34, pl. } 19\end{array}$ \\
\hline $\begin{array}{l}\text { Ostracon IFAO } \\
\text { Cat. } 1419\end{array}$ & $\$ 14$ & $\begin{array}{l}19^{\text {th }}-20^{\text {th }} \\
\text { Dynasty }\end{array}$ & $\begin{array}{l}\text { Deir el- } \\
\text { Medina }\end{array}$ & $\begin{array}{l}\text {-Posener, G., Catalogue des ostraca } \\
\text { hiératiques, } 35 \text {, pl. } 19 .\end{array}$ \\
\hline $\begin{array}{l}\text { O. E.GA } \\
6128.1943\end{array}$ & $\S 13, \S 14$ & $\begin{array}{l}\text { New } \\
\text { Kingdom }\end{array}$ & $\begin{array}{l}\text { Deir el- } \\
\text { Medina }\end{array}$ & $\begin{array}{l}\text { Hagen, F., New Kingdom Ostraca } \\
\text { from the Fitzwilliam Museum, Brill, } \\
(2011), 25 .\end{array}$ \\
\hline
\end{tabular}

Table 2: An inventory of the sources which include $\$ 14$ of the Loyalist Instruction of Kairsu

\footnotetext{
${ }^{1}$ More recently, 150 ostraca from the mortuary temple of Thutmose III were published by Hagen. It includes over 50 literary ostraca, several with wisdom instructions (Khety, Amenemhat, Man for his Son). He also discusses in detail the training of scribes and priests at the temple. Hagen, F., Ostraca from the Temple of Millions of Years of Thutmose III, Leiden, (2021), 5-8.

${ }^{2}$ Simpson, W.K., The Literature of Ancient Egypt: An Anthology of Stories, Instructions, and Poetry. New Haven and London, (1972), 198; Parkinson, R., Poetry and Culture in Middle Kingdom Egypt: A Dark Side to Perfection. London, (2002), 318-319.
} 


\section{Hieratic Commentary:}

The lines are inclined in writing. The practiced hand is of the copyist shows that was not a beginner.

Line 1.a 4 : Traces at the beginning represent 11 as suggested by Ostracon IFAO Cat. $1236 .^{1}$

Line 1.b The text carries three verse-points in black ink, these invariably occur at the end of semantic and syntactic units, the "verses". Verse points are common in literary papyri. Perhaps the best-known early paratextual markers, the so-called "verse points," "structuring points" and "rhythm-points" are dated to the Late Middle Kingdom. ${ }^{2}$ They are found above the hieratic signs like most other literary manuscripts.

However, a notable deviation of standard practice is the black colour of verse-points, which are usually added in red ink. For Gardiner red verse-points should be termed punctuation. ${ }^{3}$ It appears between lines on horizontal lines in black rather than the usual red. ${ }^{4}$ These marks are indications of the metric system, perhaps for the one reciting ${ }^{5}$. They marked a combination of stress and pause.

Line 1.c 2 : In this word, the scribe may be mistaken in his writing by using a form that looks like 1 . The normal forms of the word were written with the sign 9 or .

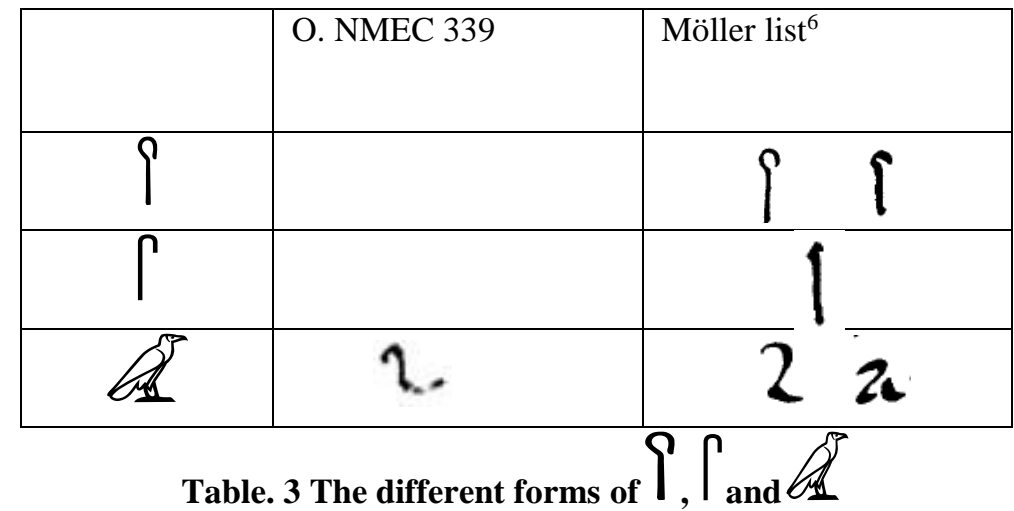

Line 1.d 1 : The trace at the end of this line may be according to Ostracon IFAO Cat. 1236.

\footnotetext{
${ }^{1}$ Posener, G., Catalogue des ostraca hiératiques littéraires de Deir el Médineh, Tome 2 (Nos 1109 à 1266), DFIFAO 18, 1951, 35, pl. 59-59 a.

${ }^{2}$ Nassar, N., 'Writing Practices in El-Lahun Papyri during the Middle Kingdom,' JARCE 55, (2019), 111.

${ }^{3}$ Gardiner, A., The Library of A. Chester Beatty. Description of a hieratic papyrus with a mythological story, love-songs, and other miscellaneous texts. (The Chester Beatty Papyri. 1), London, (1931), 2.

${ }^{4}$ Ogden, G., 'Writing Ramesside Hieratic: What the Late-Egyptian Miscellanies Tell us about Scribal Education,' in: Sue D'Auria (ed.) Servant of Mut: Studies in Honor of Richard A. Fazzini, Leiden, (2008), 109.

${ }^{5}$ Tacke, N., Verspunkte als Gliederungsmittel in Ramessidischen Schülerhandschriten, SAGA 22, Heidelberger Orientverlag, (2001), 137-145.

${ }^{6}$ Möller, G., Hieratische Paläographie. Die aegyptische Buchschrift in ihrer Entwicklung von der fünften Dynastie bis zur römischen Kaiserzeit, Vol. II, Leipzig, (1927).

${ }^{7}$ Posener, G., Catalogue des ostraca hiératiques littéraires de Deir el Médineh, Tome 2 (Nos 1109 à 1266), 35, pl. 59-59 a.
} 
Line 2.a : The beginning of this line is very faint. This part may represent shape of the same sign in the first line over $n b \underset{\text {. }}{\square}$.

Line 3.a $\mathbb{L}_{0}:$ : The trace at the end of this line may represent 9 , according to $\mathrm{P}$. Louvre E4864. ${ }^{1}$

Line 4.a

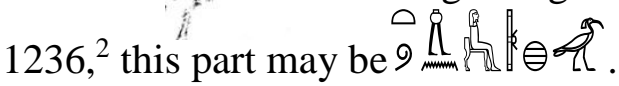

Line 5.a $\sim_{\text {, e }}$ : This line may represent $\equiv \subset \subset \odot$. The date has been interpreted as a sign that the ostracon is a scribal exercise. ${ }^{3}$ However, if this fragment is an educational text and the signs in Line 5 represent the date, this practice is usual as the date was written at the end of the educational text in red ink and not black as is the case in this fragment. ${ }^{4}$

\section{Commentary:}

The comments on the papyrus depend on a comparative study with another version of section 14 of the Loyalist Instruction of Kairsu (table 4).

(1) $\mathrm{C} 3 \mathrm{hr} \mathrm{rmt}$ : According to Ostracon IFAO Cat. $1236,{ }^{5}$ the beginning of the line can be completed to 11 ¿ Instruction of Kairsu.

(2) $m i$ sšr: the scribe replaced the preposition $m$ with $m i$.

(3) ${ }^{\circ} w t$ : The scribe writes the word ${ }^{c} w t$ with the form $\pi R$. The normal form is is ?

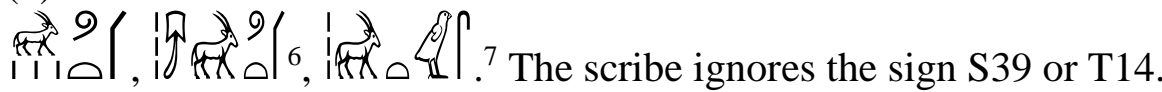

(4)This damaged part represents $\$ 14.4$ and $§ 14.5$.

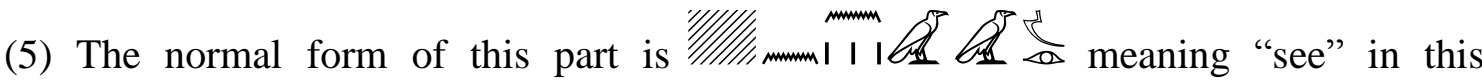
ostracon the scribe used another form I I I used the plural strokes as the more common Late Egyptian writing of the third person plural pronouns ( $w$, "they"/ "one").

${ }^{1}$ Posener,G., L'enseignement loyaliste. Sagesse égyptienne du Moyen Empire, 144.

${ }^{2}$ Posener, Catalogue des ostraca hiératiques littéraires de Deir el Médineh, Tome 2 (Nos 1109 à 1266), 35, pl. 59-59 a.

${ }^{3}$ McDowell A.G., 'Student Exercises from Deir el-Medina: the Dates,' in P. Der Manuelian (ed.), Studies in honor of William Kelly Simpson, 2, Boston, (1996), 600-608; Hagen, F., New Kingdom Ostraca from the Fitzwilliam Museum. Cambridge, 26.

${ }^{4}$ McDowell A.G., in P. Der Manuelian (ed.), Studies in honor of William Kelly Simpson, 2, Boston, (1996), 600-608; Kaper, O., 'A Kemyt Ostracon from Amheida, Dakhleh Oasis,' BIFAO 110, (2010), 118.

${ }^{5}$ Posener, G., Catalogue des ostraca hiératiques, 35, pl. 60-60 a; Posener, G., L'enseignement loyaliste. Sagesse égyptienne du Moyen Empire, 138.

${ }^{6} \mathrm{LD}$ I, 62.

${ }^{7} \mathrm{~Wb} \mathrm{I}, 170$. 
(6) `nn: the interesting variant in this ostracon is using the verb ${ }^{\prime} n n \Lambda$ ("to return", "to turn back"), not "still", instead of $m n w$ which appeared on Ostracon IFAO Cat. $1238^{1}$ and Tablet Carnarvon II. ${ }^{2}$ This matches the meaning captured by Posener well, with a clearer wording: "Watch your ka-priests; if the son is neglectful, the wab-priest will still return" (to look after the cult of the deceased, even if the son neglects his duty).

(7) We restore $\underline{d} d w$ at the ending of the line, followed by the end of $\$ 14.8$

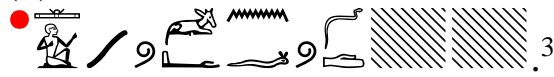

(8) in.tw: Based on the previous line and general context of the text, one expects an active verb form. But the scribe used the passive article $(t w)$ to represent the passive form of subjunctive $s \underline{d} m . f$.

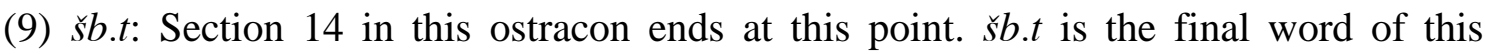
paragraph, although there is space left on the ostracon for more words, the scribe chose to stop here and write the date below.

(10) Dating formula: The date formula at the end of the literary text was one of the teaching text features, usually written in red ink. In this ostracon, it was written in black ink at the end of the text. Another unusual feature of this fragment regarding its date is that it is written briefly and intentionally abbreviated (month and season are left out, despite the available space).

So far, this abbreviated from of the date did not appear before, although there was enough space to write it entirely in ostraca from this genre.

McDowell mentioned that the education in Deir el-Medina was on days off, when all the workmen were at home, rather than at the work place in the Valley of the Kings. ${ }^{4}$ This ostracon is dated to Day 24, which was a weekday in the third week of the month. ${ }^{5}$ The same date (Day 24) is mentioned in the Kemyt Ostracon from Amheida, Dakhleh Oasis. $^{6}$

The weekdays actually appear to be working days; however, this was not actually true in some cases as they were not always working days. ${ }^{7}$ The evidence for that is a gathering of the knbt at Deir el-Medina on Day 24; that day did not usually concur with a working day. ${ }^{8}$

\footnotetext{
${ }^{1}$ Posener, G., Catalogue des ostraca hiératiques, 35, pl. 60-60 a.

${ }^{2}$ Posener,G., L'enseignement loyaliste. Sagesse égyptienne du Moyen Empire, 143.

${ }^{3}$ Posener,G., L'enseignement loyaliste. Sagesse égyptienne du Moyen Empire, 144

${ }^{4}$ McDowell A.G., in P. Der Manuelian (ed.), Studies in honor of William Kelly Simpson, 2, Boston, (1996), 603.

${ }^{5}$ The same day appeared in these ostraca: II 3ht 24 (DM 1523), I 3ht 24 (DeM 1113), II šmw 24 (Cairo '217), [...] 24 (DM 1377) AI, [...] 24 (DM 1377) AI. See McDowell A.G., in P. Der Manuelian (ed.), Studies in honor of William Kelly Simpson, 2, Boston, (1996), 602-606.

${ }^{6}$ The date of the ostracon is 3bd 3 3ht sw 24. Kaper, O., BIFAO 110, (2010), 115-126.

${ }^{7}$ Jauhiainen, H., "Do Not Celebrate Your Feast Without Your Neighbours": a Study of References to Feasts and Festivals in Non-Literary Documents from Ramesside Period Deir el-Medina, Publications of the Institute for Asian and African Studies 10, (2009), 58-63.

${ }^{8}$ Vleeming, S.P., 'The days on which the knbt used to gather,' in Demarée, R.J and Janssen, Jac. J.(eds), Gleanings from Deir el-Medîna, EgUit 1, (1982), 185.
} 


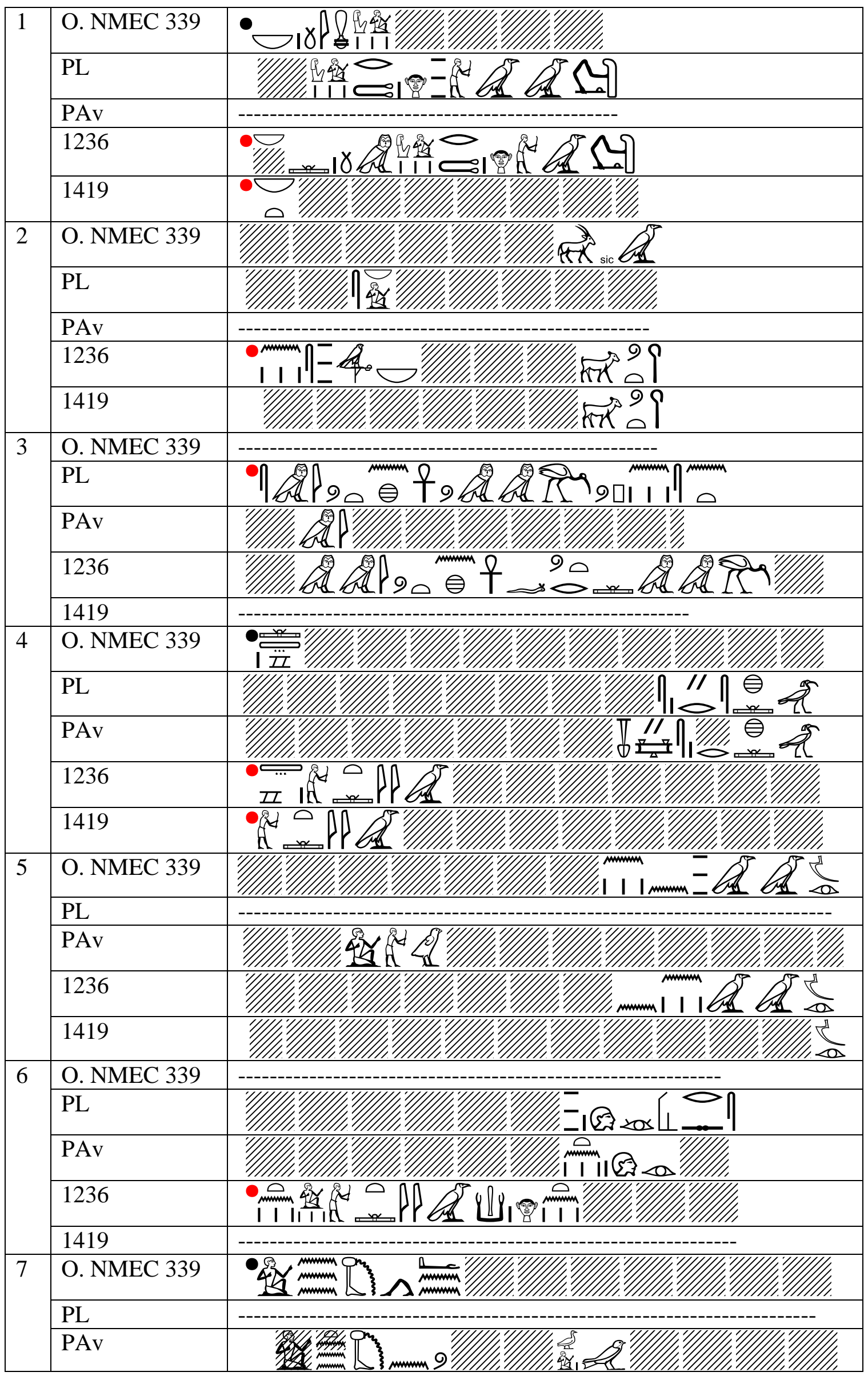

Loyalist Instruction of Kairsu: Section 14 (O. NMEC 339) - 33 - 


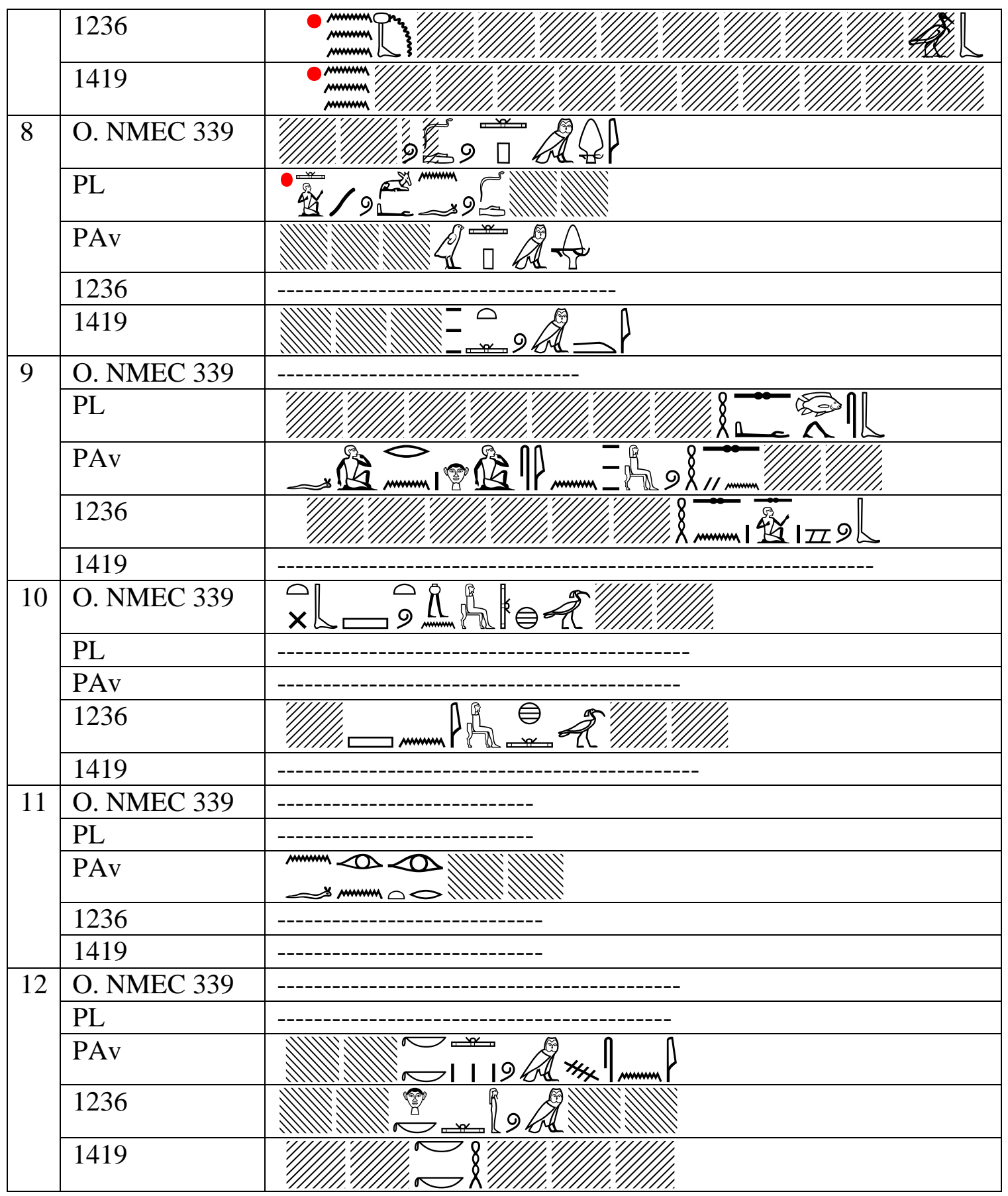

Table 4: A synoptic edition of the final section of Kairsu 


\section{Bibliography}

1- Allen, J., Middle Egyptian Literature: Eight Literary Works of the Middle Kingdom. Cambridge: Cambridge University Press, (2015).

2- André de Campos Silva, The Roles of God in the Ancient Egyptian Instruction Texts of the Middle and New Kingdoms, PhD thesis, Universidade de Lisboa (2019).

3- Barbotin, C., 'Les ostraca hiératiques de l'école du Ramesseum', Memnonia 24, (2013), 73-79.

4- Berlev, O.D.,'Une méthode pour dater les stèles du Moyen-Empre (la formule : “Ôvous, les vivants, ceux qui sont sur terre”),' КСИНА 46, (1962), 45-87.

5- Burkard, G., Textkritische Untersuchungen zu ägyptischen Weisheitslehren des Alten und Mittleren Reiches, Äg.Abh 34, (1977).

6- Buzov, E., 'Notes on Egyptian Wisdom texts,' JES IV, (2015), 49-83.

7- Canhão, T., A literatura egípcia do Império Médio: espelho de uma civilização, $\mathrm{PhD}$ thesis, University of Lisbon, (2010).

8- -----------., Textos da literatura egípcia do Império Médio: Textos hieroglíficos, transliterações e traduções comentadas. Lisbon: Fundação Calouste Gulbenkian, (2014).

9- Carreira J. N., Filosofia antes dos Gregos, Biblioteca universitária 71, (1994).

10- Chappaz, J.-L. 'Un nouvel ostracon de l'Enseignement loyaliste,' BSÉG 7, (1982), 3-10.

11- Dorn, A., 'Die Lehre Amunnachts,' Z̈̈S 131, (2004), 38-55.

12- Erman, A\& Grapow, H., Wörterbuch der ägyptischen Sprache, 6 vols, Berlin.

13- Fox, M. V., 'The Social Location of the Book of Proverbs,' in Fox, M. V. (eds.) Texts, Temples, and Traditions: A Tribute to Menahem Haram, Victor Avigdor Hurowitz, Avi Hurvitz, Michael L. Klein, Baruch J. Schwartz, and Nili Shupak, Winona Lake, Indiana: Eisenbrauns, (1996), 227-239.

14- Gardiner, A. H., Chester Beatty Gift, HPBM $3^{\text {rd }}$ series, London (1935).

15- -----------., The library of a.Chester Beatty description of a hieratic papyrus with a mythological story, love-songs, and other miscellaneous texts, London, (1931).

16- Hagen, F., An Ancient Egyptian Literary Text in Context: The Instruction of Ptahhotep, Orientalia Lovaniensia Analecta 218. Leuven: Peeters, (2012).

17- ............. New Kingdom Ostraca from the Fitzwilliam Museum, Cambridge. Leiden: Brill, (2011).

18- ----------., Ostraca from the Temple of Millions of Years of Thutmose III, Leiden, (2021).

19- Jauhiainen, H., "Do Not Celebrate Your Feast Without Your Neighbours": a Study of References to Feasts and Festivals in Non-Literary Documents from Ramesside Period Deir el-Medina, Publications the Institute for Asian and African Studies 10, (2009).

20- Kaper, O., 'A Kemyt Ostracon from Amheida, Dakhleh Oasis,' BIFAO 110, (2010), 115-126.

21- Leblanc, C., 'L'école du temple (ât-sebait) et le per-ankh (maison de vie). À propos de récentes découvertes effectuées dans le contexte du Ramesseum', Memnonia 15, (2004), 93-101.

22- Leprohon, R.J., 'The Stela of Sehetepibre (CG 20538) Borrowings and Innovation,' in: Silverman, D.P., Simpson, W.K.and Wegner, J. (eds.), Archaism and Innovation: Studies in the Culture of Middle Kingdom Egypt, Yale University, (2009), 277- 290.

23- Lesko, L., A Dictionary of Late Egyptian, $2^{\text {nd }}$ edition, 2 vols, USA, 2004. 
24- Lichtheim, M., 'Didactic Literature,' in Loprieno, A. (ed.) Ancient Egyptian Literature. History and Forms, Leiden - New York - Koln, (1996), 243-263.

25- ----------, Moral Values in Ancient Egypt, Orbis Biblicus et Orientalis 155. Fribourg, Switzerland: University Press; Göttingen: Vandenhoek und Ruprecht. (1997).

26- Loprieno, A., 'Loyalistic Instructions,' in Loprieno, A., Ancient Egyptian Literature: History and Forms, Probleme der Ägyptologie 10. Leiden: Brill, (1996), 404-412.

27- McDowell A.G., 'Student Exercises from Deir el-Medina: the Dates,' in: P. Der Manuelian (ed.), Studies in honor of William Kelly Simpson, 2, Boston, (1996), 601-608. 28- Möller, G., Hieratische Paläographie. Die aegyptische Buchschrift in ihrer Entwicklung von der fünften Dynastie bis zur römischen Kaiserzeit, Vol. II, Leipzig, (1927).

29- Müller, M. 'Ostraka aus dem Totentempel des Merenptah in Theben', in ToivariViitala; J. Vartiainen, T.; Uvanto S. (eds.), Deir el-Medina Studies: Helsinki June 2426, 2009 Proceedings (The Finnish Egyptological Society Occasional Publications 2), Vantaa: Multiprint, (2014), 144-153.

30- Nassar, N., 'Writing Practices in El-Lahun Papyri during the Middle Kingdom,' JARCE 55, (2019), 96-116.

31- Ogden, G., 'Writing Ramesside Hieratic: What the Late-Egyptian Miscellanies Tell us about Scribal Education,' in: Sue D'Auria (ed.) Servant of Mut: Studies in Honor of Richard A. Fazzini, Leiden, (2008), 102-110.

32- Parkinson, R. B., Poetry and Culture in Middle Kingdom Egypt: A Dark Side to Perfection, London: Continuum, (2002).

33- Posener, G., Catalogue des ostraca hiératiques littéraires de Deir el Médineh, Tome 2 (Nos 1109 à 1266), DFIFAO 18, (1951).

34- --------, L'enseignement loyaliste. Sagesse égyptienne du Moyen Empire. Geneva: Droz. (1976).

35- Schipper, B., "Von der "Lehre des Sehetp-jb-Re" zur "Loyalistischen Lehre". Überlegungen zur Überlieferungsgeschichte loyalistischer Aussagen,' Z̈̈S 125, (1998), 161-179.

36- Schneider, Th., 'Scribes, Sages, and Seers in Ancient Egypt,' In Leo G. Perdue (eds.), Scribes Sages, and Seers: The Sage in the Eastern Mediterranean World, Forschungen zur Religion und Literatur des Alten und Neuen Testaments 219, Göttingen: Vandenhoek und Ruprecht, (2008), 35-46.

37- Simpson, W.K., The Literature of Ancient Egypt: An Anthology of Stories, Instructions, and Poetry. New Haven and London, (1972).

38-Tacke, N., Verspunkte als Gliederungsmittel in Ramessidischen Schülerhandschriten, SAGA 22, Heidelberger Orientverlag, (2001).

39-Verhoeven, U., 'Von der 'Loyalistischen Lehre' zur 'Lehre des Kai'rsu,' ZAS 136, (2009), 87-98.

40- Vernus, P., Sagesses de l'Égypte pharaonique. 2nd ed. rev. Arles: Actes Sud, (2010).

41- Vleeming, S.P., 'The days on which the knnbt used to gather,' in: Demarée, R.J. and Janssen, Jac.J. (eds.), Gleanings from Deir el-Medîna, EgUit 1, (1982), 183-192.

42- Williams, R., 'Scribal Training in Ancient Egypt,' JAOS 92 (1972), 214-221.

43- --------, 'The Sages of Ancient Egypt in the Light of Recent Scholarship,' JAOS 101 (1981), 1-19. 


\section{PLATES}
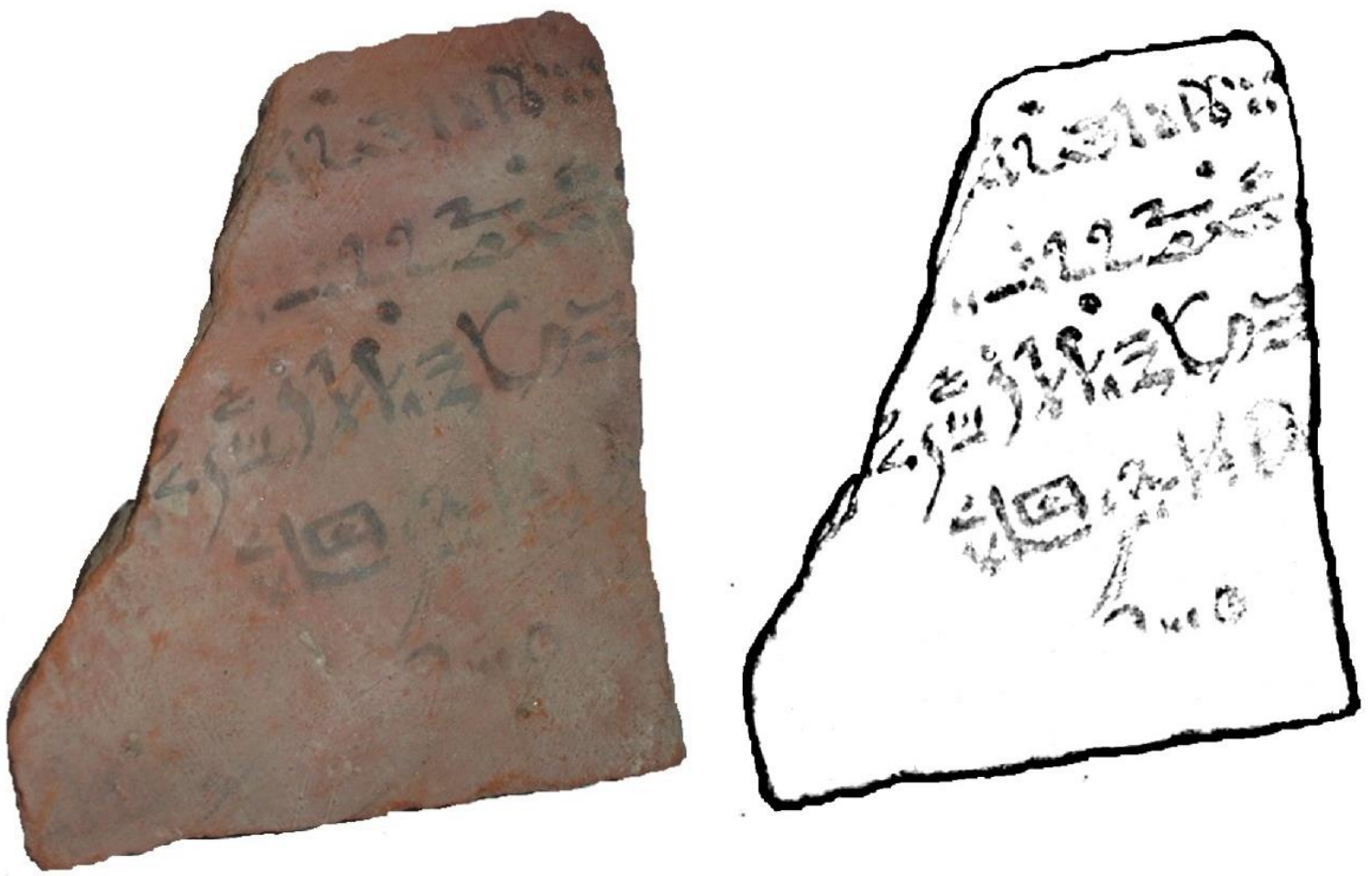

Pl. 1: O. NMEC 339 (C) the National Museum of

Pl.2:Facsimile of O. NMEC 339 (by Marwa A. Ewais) Egyptian Civilization at Cairo

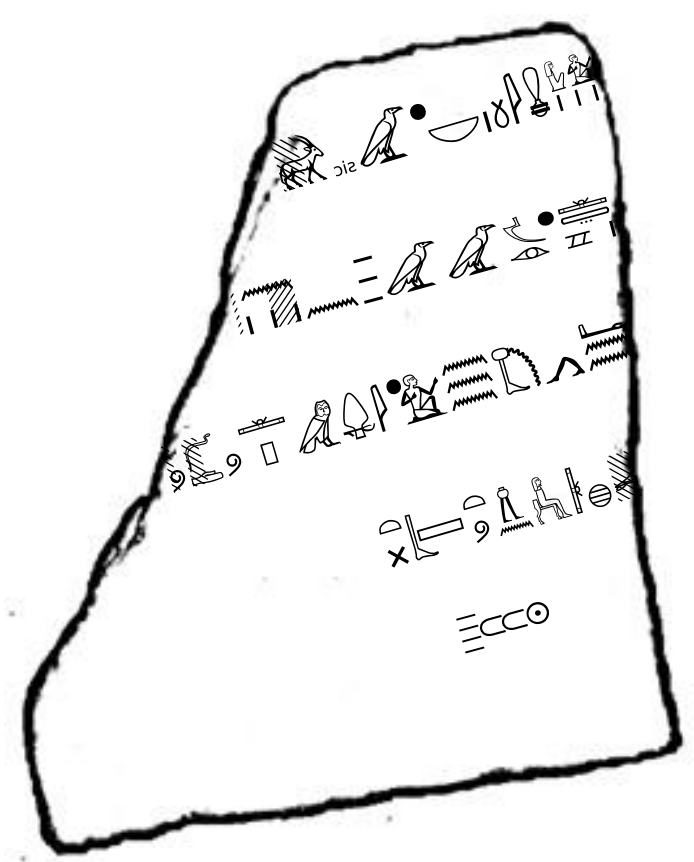

Pl.3: Transcription of O. NMEC 339 (by Marwa A. Ewais) 